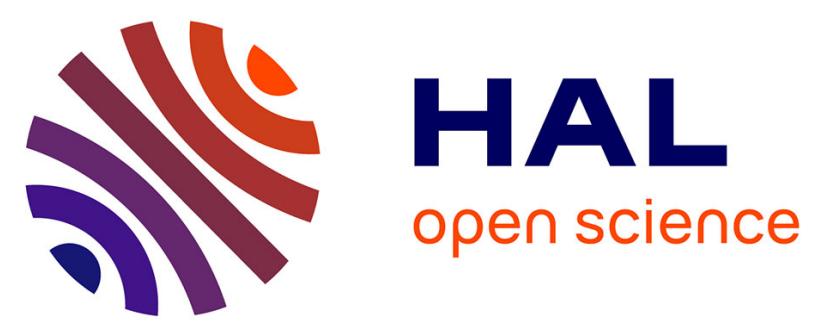

\title{
Cosmet'eau -Changes in the personal care product consumption practices: from whistle-blowers to impacts on aquatic environments
}

Adèle Bressy, Catherine Carré, Émilie Caupos, Bernard de Gouvello, José-Frédéric Deroubaix, Jean-Claude Deutsch, Romain Mailler, Anthony Marconi, Pascale Neveu, Laurent Paulic, et al.

\section{To cite this version:}

Adèle Bressy, Catherine Carré, Émilie Caupos, Bernard de Gouvello, José-Frédéric Deroubaix, et al.. Cosmet'eau -Changes in the personal care product consumption practices: from whistle-blowers to impacts on aquatic environments. Environmental Science and Pollution Research, 2016, 23 (13), pp.13581-13584. 10.1007/s11356-016-6794-y . hal-01348249

\section{HAL Id: hal-01348249 \\ https://hal-enpc.archives-ouvertes.fr/hal-01348249}

Submitted on 22 Jul 2016

HAL is a multi-disciplinary open access archive for the deposit and dissemination of scientific research documents, whether they are published or not. The documents may come from teaching and research institutions in France or abroad, or from public or private research centers.
L'archive ouverte pluridisciplinaire HAL, est destinée au dépôt et à la diffusion de documents scientifiques de niveau recherche, publiés ou non, émanant des établissements d'enseignement et de recherche français ou étrangers, des laboratoires publics ou privés. 


\title{
Cosmet'eau- Changes in the personal care product consumption practices: from whistle-blowers to impacts on aquatic environments
}

\author{
Adèle Bressy ${ }^{1}$, Catherine Carré1,2, Émilie Caupos ${ }^{1}$, Bernard de Gouvello ${ }^{1,3}$, José-Frédéric Deroubaix ${ }^{1}$, Jean-Claude Deutsch ${ }^{4}$, \\ Romain Mailler ${ }^{5}$, Anthony Marconi ${ }^{6}$, Pascale Neveu ${ }^{7}$, Laurent Paulic ${ }^{6}$, Sébastien Pichon ${ }^{5}$, Vincent Rocher ${ }^{5}$, Irina Severin ${ }^{4}$, \\ Mathilde Soyer ${ }^{1}$, Régis Moilleron ${ }^{1}$ \\ ${ }^{1}$ Leesu, UMR-MA 102, École des Ponts, UPEC, AgroParisTech, UPE, Paris, France; ${ }^{2}$ Ladyss, UMR 7533, Université Paris-Sorbonne, Paris, France; \\ ${ }^{3} \mathrm{CSTB}$, Paris, France; ${ }^{4}$ Arceau-IdF, Paris, France; ${ }^{5}$ SIAAP, Direction du Développement et de la Prospective, Colombes, France; ${ }^{6}$ Tronico VigiCell, \\ La Roche-sur-Yon, France; ${ }^{7}$ Ville de Paris, Services techniques de l'eau et de l'assainissement, Paris, France
}

Corresponding authors: Dr. Adèle Bressy (adele.bressy@enpc.fr) and Pr. Régis Moilleron (moilleron@u-pec.fr)

Keywords: consumption practices, endocrine disruptors, micropollutants, parabens, personal care products, source reduction, urban water cycle, whistle-blowers

\begin{abstract}
The Cosmet'eau project (2015 - 2018) investigates the "changes in the personal care product (PCP) consumption practices: from whistle-blowers to impacts on aquatic environments." In this project, the example of PCPs will be used to understand how public health concerns related to micropollutants can be addressed by public authorities - including local authorities -, industries and consumers. The project aims to characterize the possible changes in PCP consumption practices and to evaluate the impact of their implementation on aquatic contamination. Our goals are to study the whistle-blowers, the risk perception of consumers linked with their practices and the contamination in parabens and their substitutes, triclosan and triclocarban from wastewater to surface water. The project investigates the following potential solutions: modifications of industrial formulation or changes in consumption practices. The final purpose is to provide policy instruments for local authorities aiming at building effective strategies to fight against micropollutants in receiving waters.
\end{abstract}

\section{Introduction}

Micropollutants are a "Challenge in aquatic systems" as said by Schwarzenbach et al. in Science (2006). These authors identified three ways to investigate the micropollutant issue: assessing their impact on aquatic life and human health, exploring and implementing water-treatment technologies, and last but not least minimizing the introduction of critical pollutants into the aquatic environment (Schwarzenbach et al. 2006). A large and growing body of literature has investigated the first two challenges (Tusseau-Vuillemin et al. 2007; Cladiere et al. 2010; Gourlay-Francé et al. 2011; Bressy et al. 2012; Liu and Wong 2013; Luo et al. 2014; Margot et al. 2015; Mailler et al. 2015) but few have 
focused on the third one. The Cosmet'eau project is willing to focus on this third challenge linking consumption practices and micropollutants in the urban water cycle, using the example of cosmetics. Besides, micropolluants are not only a substance issue, they are also linked to issues of consumption practices (Moilleron 2015, personal communication).

The substances used in the formulation of most personal care products (PCPs) are found ubiquitously in surface waters worldwide (Yu et al. 2011; Brausch and Rand 2011; Liu and Wong 2013). Among them, parabens (PBS), triclosan (TCS) and triclocarban (TCC) are widely used in the composition of personal care products (PCPs), pharmaceuticals and other consumer products as antiseptic or conservative (Bedoux et al. 2012; Haman et al. 2015). These substances are of increasing concern due to their wide utilization (Mintel database 2015; Ficheux et al. 2015), and their potential negative effect on aquatic ecosystems as endocrine disruptors or induction of antibiotic resistance (Gomez et al. 2005; SCCS 2010; Brausch and Rand 2011; Yamamoto et al. 2011; Carey and McNamara 2015; Haman et al. 2015). Occurrence of PBs, TCS and TCC has been studied in wastewater and in wastewater treatment plants discharges (WWTP) (Bedoux et al., 2012; Gasperi et al., 2014; Haman et al., 2015). But only few data are available for greywater (Eriksson et al., 2009) and surface waters in particular in France (Botta et al. 2014). Even if the levels observed in aquatic environment seem too low to produce adverse effects (Gomez et al. 2005; Brausch and Rand 2011; Yamamoto et al. 2011), the ubiquitous occurrence of these substances is alarming since long term, low-dose and cocktail effects have not been assessed (Halden 2014a).

Besides, these substances are interesting for social science studies since their fate are linked to whistleblowers. In France, parabens have been the subject of a specific alert. In 2005 the French TV show "Envoyé Spécial" revealed being a key moment in the alert process, reporting a suspected link between parabens and breast cancers by scientists (Dardre et al., 2004). This alert led to the emergence of "paraben free" or "organic" products and to changes both in the industry and consumer practices. Indeed Figure 1 shows a strong decrease on the use of parabens in cosmetic products. In the United States, a controversy arose concerning the use of triclosan (Halden 2014a; Halden 2014b; DeLeo and Sedlak 2014). Two findings emerged from these observations: (i) the changes in practices were led by industries without any formal regulations and (ii) few questions were raised by the public authorities and consumers on the safety of substitutes.

For both environmental and health issues, there is a need of a better understanding of the fate of these substances in the urban cycle and of their harmful effects. Moreover, we need to understand the different steps leading to citizen and elected representative awarness and actions to regulate the diffusion of micropollutants, especially endocrine disruptors as bisphenol $A$ and parabens (Chateauraynaud 2013). Sociologists' part of Cosmet'eau project investigate these molecules to show the alert and identify more precisely the stakeholder involved (scientists, media, NGOs, politicians...) 
in the alert process. Parabens and bisphenol A are case studies, and our objective is to elaborate a wider pattern on how a new risk can be turned into public issues and public policies. This project investigates the potential solutions: from the source by industrial formulation modifications, to the downstream point of the system encouraging consumers to be vigilant and to change their consumption practices. The final purpose is to propose policy instruments for local authorities aiming at building effective strategies to fight against micropollutants in receiving waters. Indeed, facing the scientific controversies, local authorities feel powerless to deliver messages. The question is on which strategy to promote: a global planified approach of vigilance or a molecule-by-molecule strategy which would focus on a list of priority substances.

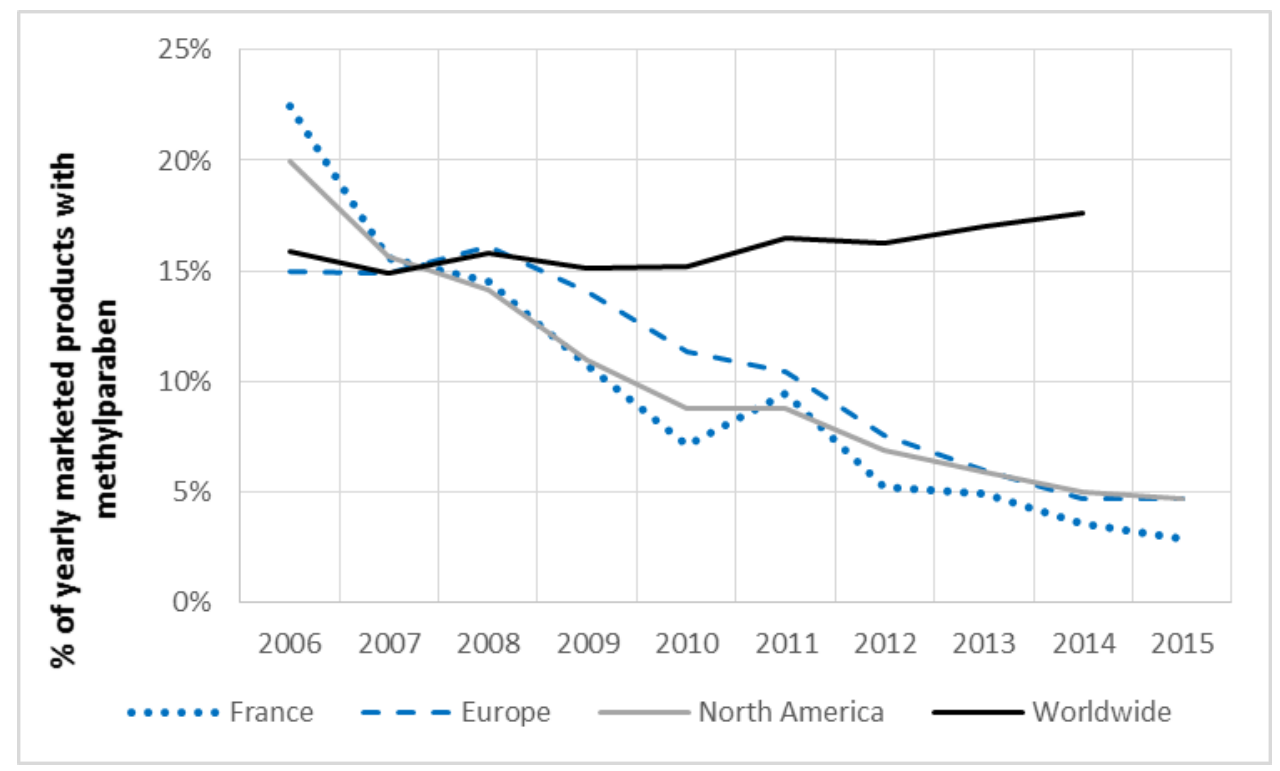

Figure 1: Evolution of percentages of yearly marketed products containing methylparaben since 2016

\section{Cosmet'eau objectives}

The first objective is to study whistle-blowers and their influence on consumer and government awareness and responses. The second objective is to develop innovative technical and sociological tools for monitoring both consumption practices and levels of contamination. The third objective is to understand the motivation of people changing their practices. The fourth objective is to monitor the levels of contamination from wastewater up to surface waters, and their evolution due to changes in practices. And finally we want to propose innovations in governance: towards the changes in consumption practices that could be encouraged by the (local) authorities in order to reduce the source of micropollutants. 


\section{Cosmet'eau methodology}

Cosmet'eau is an interdisciplinary project involving chemists, ecotoxicologists, geographers, urban hydrologists and sociologists. The project is divided into 7 workpackages (WPs) listed on the Figure 2. WP1 will present the state of the art concerning each field covered by the project.

WP2 aims to develop innovative methodologies, both on technological and sociological aspects, (i) to understand the consumption practices leading to the release of micropollutants, (ii) to monitor the substances in the urban water and (iii) to measure their impacts. In particular, a passive sampling method will be developed for triclosan and triclocarban based on polymeric membranes (Bressy et al. 2013) and an analytical method to screen parabens substitutes will be optimised by high resolution mass spectrometry. An array of bioassays, including overall toxicity, endocrine disruption, genotoxicity will be implemented on different types of urban waters from greywater up to receiving waters.

For WP3, the humanities and social sciences will focus on whistle-blowers and how the alert is launched, between amplification in some cases and denial in some others. They will question all the actors involved in the alert: scientists, associations, specialized or generalist media relaying the issue, and politicians and legislators.

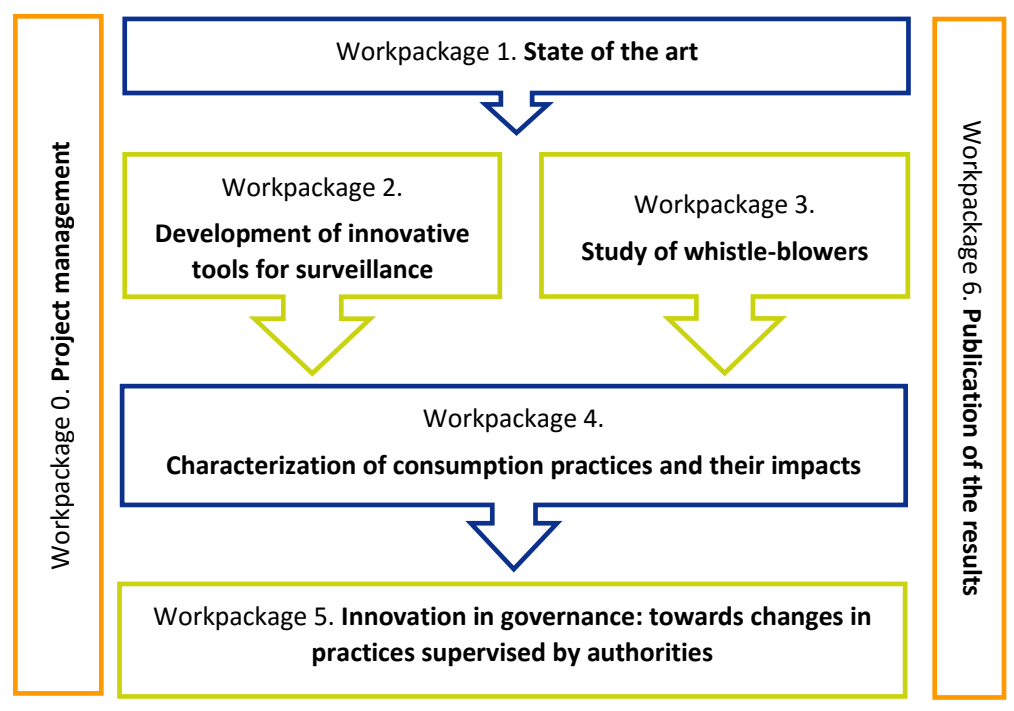

Figure 2: Cosmet'eau workpackages

The tools developed in WP2 will be used in WP4 in order to characterize the changes in the consumption practices and their impact in terms of chemical and ecotoxicological environmental contamination. The mechanisms leading to a change in the risk perception and the consumption practices will be studied by the geographers and sociologists to learn about the type of discourses that are relevant to communicate about risks and source reduction. The chemists will assess the contamination by parabens, triclosan and triclocarban at different levels of the urban water cycle at the scale of the Paris conurbation, which encompasses the consumption practices of about 8 million people, i.e., $13 \%$ of the French population. Greywater, hospital effluent, wastewater before and after 
wastewater treatment plants (WWTPs), combined sewer overflows and the Seine River upstream and downstream Paris will be sampled and analysed. In particular, concentrations in the main seven sewer trunks of the Paris conurbation will be compared between 2009 (Gasperi et al., 2014) and 2016 to evaluate the efficiency of the paraben substitution. The ecotoxicological potential of this substitution will be assessed by producing greywater with different kind of cosmetic products representing different consumption practices.

WP5 aims to jointly interpret the data set and the results obtained in the previous WPs with the goal of a source reduction of micropollutants driven by communities.

WP6 will focus on the transfer and broadcast of the results issued from the previous WPs in order to be used for micropollutants public policies at local level. Several tools will be developed and adapted according to the project progress and requirements.

\section{Cosmet'eau partners}

The Cosmet'eau project is managed by the Leesu research group (http://leesu.univ-paris-est.fr/) and brings together public and private actors in the field of water: the Leesu laboratory, two stakeholders - the Public Sanitation of the Paris conurbation (SIAAP, http://www.siaap.fr/siaap/) and the City of Paris (http://www.paris.fr/) -, a SME in ecotoxicology field Tronico-VigiCell (http://www.vigicell.fr/) and an association dedicated to the promotion of research Arceau-IdF (http://arceau-idf.fr/). There exists a project website Information: http://leesu.univ-paris-est.fr/Presentation-of-Cosmet-eau.html where extra information are available. The synergy between partners is exposed in Figure 3.

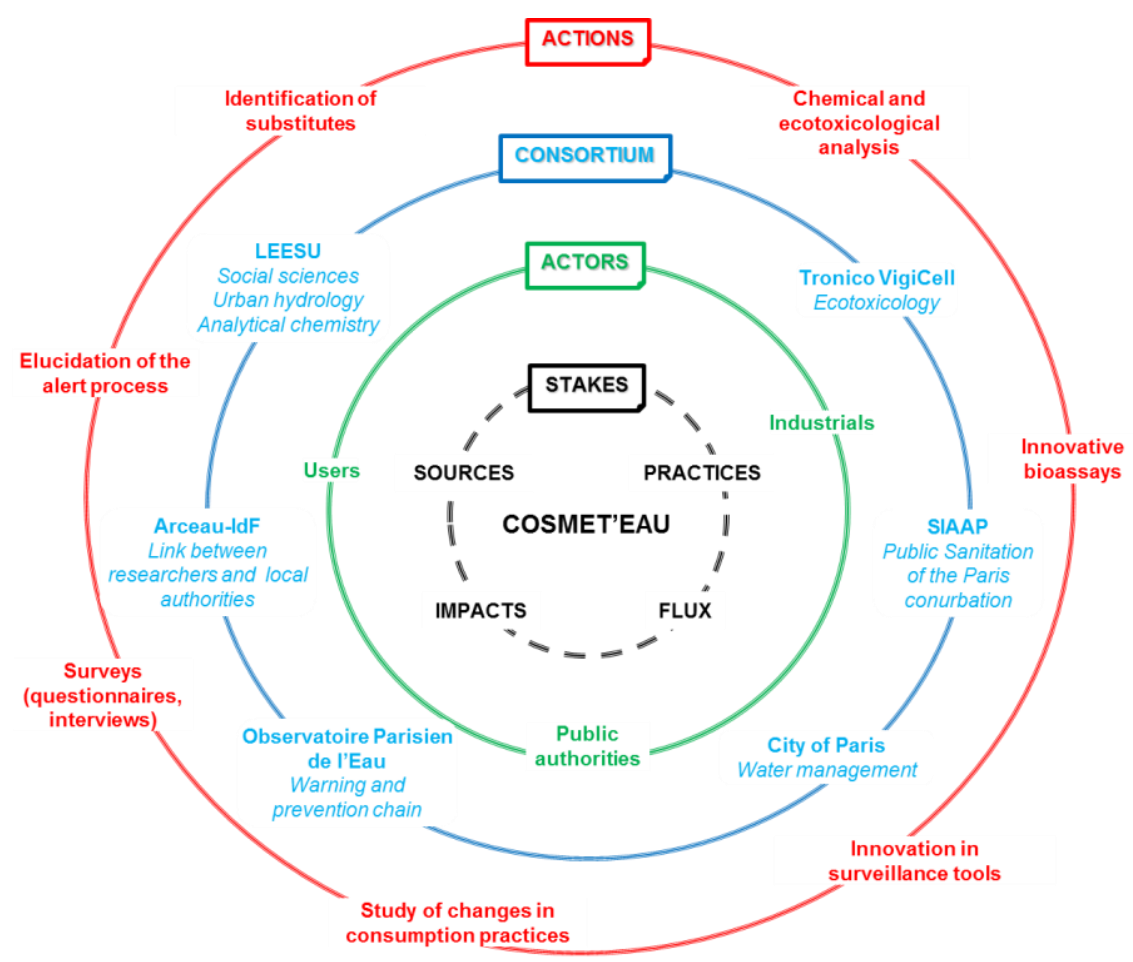

Figure 3: Cosmet'eau consortium and actions 


\section{Acknowledgments}

The Cosmet'eau project is funded within the framework of a French call for project about "Micropollutants: innovation and changes of practices" launched by the French Ministry of Environment, The French National Agency for Water and Aquatic Environments (Onema) and a French water agency (Agence de l'Eau Seine-Normandie).

\section{Reference}

Bedoux G, Roig B, Thomas O, et al (2012) Occurrence and toxicity of antimicrobial triclosan and byproducts in the environment. Environmental Science and Pollution Research 19:1044-1065.

Botta F, Alliot F, Dulio V, et al (2014) Parabens in water and sediment: occurrence in river and lakes in different rural and urban environments. Basel, Switzerland,

Brausch JM, Rand GM (2011) A review of personal care products in the aquatic environment: Environmental concentrations and toxicity. Chemosphere 82:1518-1532. doi: 10.1016/j.chemosphere.2010.11.018

Bressy A, Gromaire MC, Lorgeoux C, et al (2012) Towards the determination of an optimal scale for stormwater quality management: Micropollutants in a small residential catchment. Water Research 46:6799-6810. doi: 10.1016/j.watres.2011.12.017

Bressy A, Lorgeoux C, Mirande-Bret C, et al (2013) Ability of polymeric membranes to take into account pollution peaks: Exposure to continuous and discontinuous $\mathrm{PAH}$ pollution in pilot river.

Carey DE, McNamara PJ (2015) The impact of triclosan on the spread of antibiotic resistance in the environment. Frontiers in Microbiology. doi: 10.3389/fmicb.2014.00780

Chateauraynaud F (2013) "Lanceur d'alerte”, in Casillo I. avec Barbier R., Blondiaux L., Chateauraynaud F., Fourniau J-M., Lefebvre R., Neveu C. et Salles D. (dir.), Dictionnaire critique et interdisciplinaire de la participation, Paris, GIS Démocratie et Participation.

Cladiere M, Gasperi J, Gilbert S, et al (2010) Alkylphenol ethoxylates and bisphenol A in surface water within a heavily urbanized area, such as Paris. In: Marinov AM, Brebbia CA (eds) Water Pollution X. Wit Press, Southampton, pp 131-142

DeLeo PC, Sedlak RI (2014) Comment on "On the Need and Speed of Regulating Triclosan and Triclocarban in the United States." Environmental Science \& Technology 48:11021-11022. doi: 10.1021/es503494j

Gasperi J, Geara D, Lorgeoux C, et al (2014) First assessment of triclosan, triclocarban and paraben mass loads at a very large regional scale: Case of Paris conurbation (France). Sci Total Environ 493:854-861. doi: 10.1016/j.scitotenv.2014.06.079

Ficheux AS, Wesolek N, Chevillotte G, Roudot AC (2015) Consumption of cosmetic products by the French population. First part: Frequency data. Food and Chemical Toxicology 78:159-169. doi: 10.1016/j.fct.2015.01.016

Gomez E, Pillon A, Fenet H, et al (2005) Estrogenic Activity of Cosmetic Components in Reporter Cell Lines: Parabens, UV Screens, and Musks. Journal of Toxicology and Environmental Health, Part A 68:239-251. doi: 10.1080/15287390590895054

Gourlay-Francé C, Bressy A, Uher E, Lorgeoux C (2011) Labile, dissolved and particulate PAHs and trace metals in wastewater: Passive sampling, occurrence, partitioning in treatment plants. Water Science and Technology 63:1327-1333. 
Halden RU (2014a) On the Need and Speed of Regulating Triclosan and Triclocarban in the United States. Environmental Science \& Technology 48:3603-3611. doi: 10.1021/es500495p

Halden RU (2014b) Response to Comment on "On the Need and Speed of Regulating Triclosan and Triclocarban in the United States." Environ Sci Technol. doi: 10.1021/es5041333

Haman C, Dauchy X, Rosin C, Munoz J-F (2015) Occurrence, fate and behavior of parabens in aquatic environments: A review. Water Research 68:1-11. doi: 10.1016/j.watres.2014.09.030

Liu J-L, Wong M-H (2013) Pharmaceuticals and personal care products (PPCPs): A review on environmental contamination in China. Environment International 59:208-224. doi: 10.1016/j.envint.2013.06.012

Luo Y, Guo W, Ngo HH, et al (2014) A review on the occurrence of micropollutants in the aquatic environment and their fate and removal during wastewater treatment. Science of The Total Environment 473-474:619-641. doi: 10.1016/j.scitotenv.2013.12.065

Mailler R, Gasperi J, Coquet Y, et al (2015) Study of a large scale powdered activated carbon pilot: Removals of a wide range of emerging and priority micropollutants from wastewater treatment plant effluents. Water Research 72:315-330. doi: 10.1016/j.watres.2014.10.047

Margot J, Rossi L, Barry DA, Holliger C (2015) A review of the fate of micropollutants in wastewater treatment plants. Wiley Interdisciplinary Reviews: Water 2:457-487.

Mintel database (2015) Global market research and market insight. http://www.mintel.com.

SCCS (2010) Opinion on triclosan (antimicrobial resistance). SCCS (Scientific Committee on Consumer Safety), European Union

Schwarzenbach RP, Escher BI, Fenner K, et al (2006) The Challenge of Micropollutants in Aquatic Systems. Science 313:1072-1077. doi: 10.1126/science.1127291

Tusseau-Vuillemin M-H, Gourlay C, Lorgeoux C, et al (2007) Dissolved and bioavailable contaminants in the Seine river basin. Science of The Total Environment 375:244-256.

Yamamoto H, Tamura I, Hirata Y, et al (2011) Aquatic toxicity and ecological risk assessment of seven parabens: Individual and additive approach. Science of The Total Environment 410-411:102111. doi: 10.1016/j.scitotenv.2011.09.040

Yu Y, Huang Q, Wang Z, et al (2011) Occurrence and behavior of pharmaceuticals, steroid hormones, and endocrine-disrupting personal care products in wastewater and the recipient river water of the Pearl River Delta, South China. J Environ Monit 13:871-878. doi: 10.1039/COEM00602E 